\title{
Application of Value Engineering in Residential Building
}

\author{
Finu John ${ }^{1}$, Abraham Reji ${ }^{2}$, Annmary Vincent ${ }^{3}$, Biby Biju ${ }^{4}$, Soja Kuriakose ${ }^{5}$ \\ ${ }^{1}$ Asst Prof Civil Engineering Department, Viswajyothi College of Engineering and Technology, Vazhakulam \\ 2,3,4,5 Final year student, Civil Engineering Department, Viswajyothi College of Engineering and Technology, Vazhakulam
}

\begin{abstract}
Value engineering (VE) is a systematic method to improve the "value" of goods or products and services by using an examination of function. The current economic conditions have entailed the use of rational method and techniques and research and application of new techniques by utilizing advancements in technology in the field of production as well as in every field. Excess cost control requires to be maintained throughout the project life of building beginning from the initial stages of design. Scrutinizing the project well and considering all possible alternatives particularly in design stage are important for achieving optimum cost. In this study, how the principles of VE are applied in construction projects are going to explain, and by covering construction of a structural building as the sample project, practices of $\mathrm{VE}$ in this project are planned to describe. The satisfactory results of time and cost saving are planned to achieve by applying value engineering principles through the VE project preparation phase and project revision phase, using FAST diagram.
\end{abstract}

Key Words: Value Engineering, Optimum Cost, Function, FAST diagram

\section{INTRODUCTION}

The current construction practices require a great effort to balance the factors such as money, time and quality. Comparing with other industries it seemed that construction industry remains the toughest one to deal with. It is proven that certain modern techniques can be easily adapted to the project to balance the factors above said. Value engineering is an efficient tool among them for fostering the construction quality with an aim of low cost and high. Value engineering can be used for the following benefits.

- Cost reduction

- Time savings

- Quality improvement

- Isolation of design deficiencies

Value engineering is defined by the Society of American Value Engineers as: the systematic application of recognized techniques which identify the function of a product or service, established a value for that function and provide the necessary function reliably at the lowest overall cost. Value engineering is thus not simply a cost cutting method but improving value for service by modifying and enhancing functions. However the real objective of value engineering is value improvement. Value, as defined, is the ratio of function to cost. Value can therefore be increased by either improving the function or reducing the cost.

\subsection{Value Engineering Job Plan}

Application of Value Engineering/Analysis is done by using Job Plan which is an organized and systematic approach. VA job plan is the key of success for a value management exercise. It is through this plan that the already identified areas of value study are subjected to in depth application to seek new and creative alternatives. The Job plan required the formation of a multidisciplinary team representing a cross section of technical field to conduct the program. A multidisciplinary approach generates more and better ideas, gives greater impact of decisions and costs on all services, and develops better communication among the members of team. There are different job plan existing and are selected as per suitability of the project and requirements. Five phase job plan also known as standard job plan is the most suitable job plan of value engineering in Indian context.

\subsection{Value Engineering Methodology}

The value methodology is a systematic process that follows the Job Plan. The Job Plan consists of some phases. The recommended VE methodology (Job Plan) used by the VE team has five distinct phases. Briefly, these phases are:

\section{A. Information Phase}

In this first phase, the team attempts to understand why the project exists and who or what it is to produce. They obtain project data, present the original design or product concepts, and understand the project scope. Schedule, costs, budget, risk, and other non-monetary issues are studied until the team is comfortable with the concept of the project, what it is to produce, and who its end users are. This step also includes things like site visits and meetings with the project team, if required. Project documents like plans, drawings, specifications, and reports are obtained and the value engineering team becomes familiar with them.

\section{B. Speculation (Creative) Phase}

This phase represents the generation of improvement ideas. The team develops alternative ways that the project can perform the functions that have been identified. At this step, the functions are looked at individually and each one gets a list of alternative ways to perform the function. There is no judging between the importance of the various functions.

\section{Evaluation (Analysis) Phase}

At this stage, a priority is given to each project improvement idea. The ideas are discussed and potential costs are determined. Once the risk-reward profile of each idea is itemized, the team has determined which ideas are worth implementing into the project or feature. 
D. Development Phase

Once the value improvement options have been whittled down

\begin{tabular}{|c|l|l|l|}
\hline NO. & FUNCTION & FUNCTION COST & $\begin{array}{l}\text { CUMILATIVE } \\
\text { COST }\end{array}$ \\
\hline 1 & $\begin{array}{c}\text { Enhance } \\
\text { appearance }\end{array}$ & 602467.06 & 602467.06 \\
\hline 2 & $\begin{array}{c}\text { Remove } \\
\text { waste }\end{array}$ & 210000 & 812467.06 \\
\hline 3 & $\begin{array}{c}\text { Supply } \\
\text { power }\end{array}$ & 175000 & 987467.06 \\
\hline 4 & $\begin{array}{c}\text { Distribute } \\
\text { water }\end{array}$ & 120000 & 1107467.06 \\
\hline 5 & $\begin{array}{c}\text { Level } \\
\text { surface }\end{array}$ & 113095.18 & 1220562.24 \\
\hline 6 & $\begin{array}{c}\text { Enable } \\
\text { protection }\end{array}$ & 107922.03 & 1328484.27 \\
\hline 7 & $\begin{array}{c}\text { Facilitate } \\
\text { cleaning }\end{array}$ & 107139.14 & 1479216523.41 \\
\hline 8 & $\begin{array}{c}\text { Enhance } \\
\text { durability }\end{array}$ & 43593.2 & 15260.06 \\
\hline 9 & $\begin{array}{c}\text { Control } \\
\text { access }\end{array}$ & 40043.45 & \\
\hline
\end{tabular}

$$
\text { TOTAL }
$$$$
1519260.06
$$

Table-1 : Function cost

to the ones that make sense, the value engineering team develop the options to the point of passing them back to the original project team. They must be clearly written and explained so that the project owner and stakeholders can understand how it benefits the project and act on it. Any potential negative factors are identified. Potential costs and cost savings are itemized.

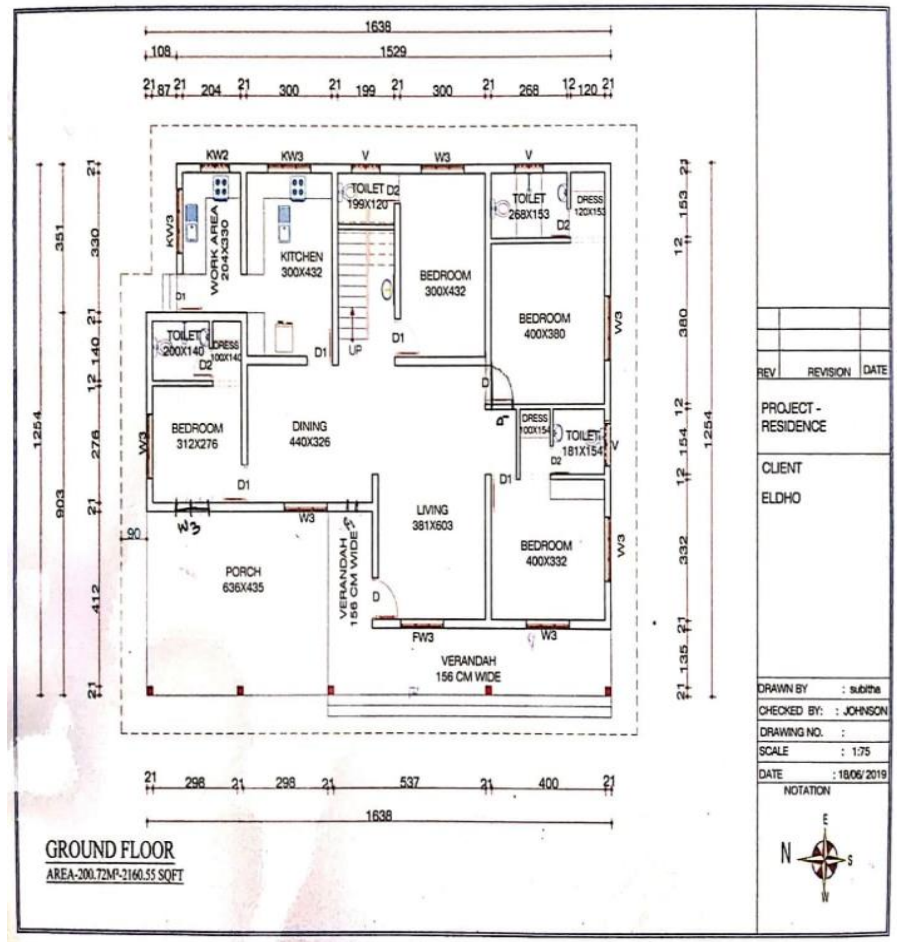

Fig -1: Plan of residential building

\section{DATA ANALYSIS}

Value Engineering is applied to a 2160.5 sq. feet residential building located in Ernakulam, Kerala, India. The information collected in the first phase of the study is as follows;
1) Owners requirements

2) Building details

3) Building Plan

4) Estimation details

5) Problems involved

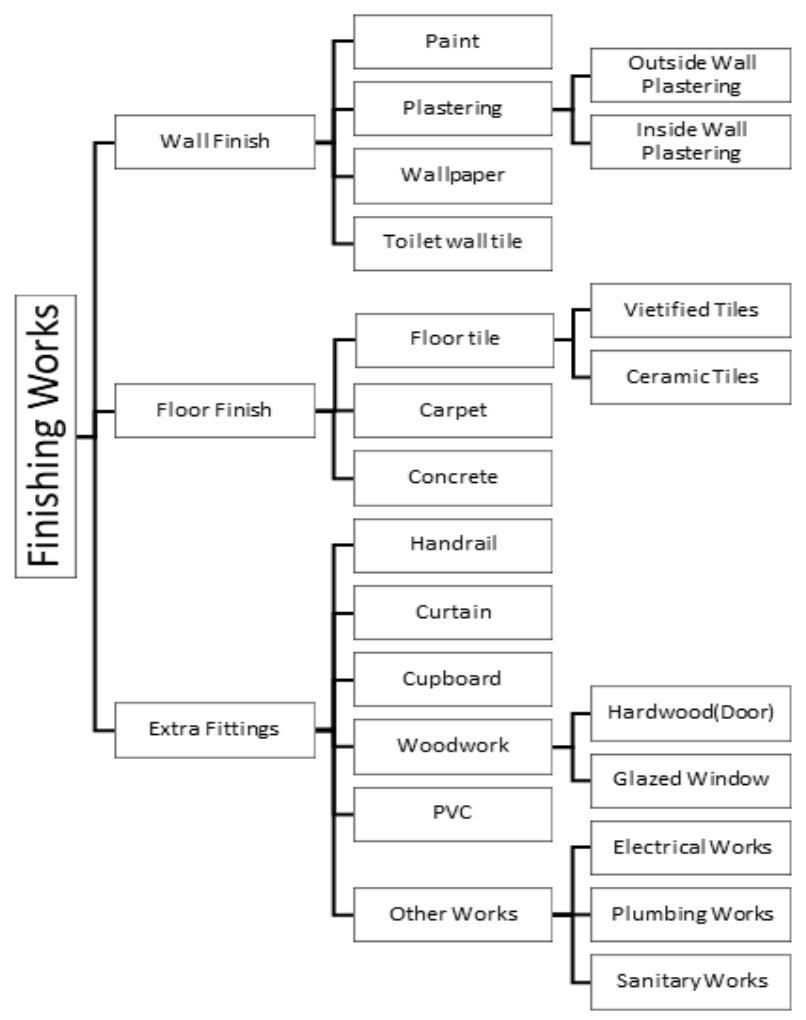

Fig -2: FAST diagram

The building is segregated into 3 sections: substructure, superstructure and roof section and done the cost analysis of each section. It is found that the finishing works in superstructure consumes more cost and are shown in fig 2 . The functions of each works in superstructure is analyzed and evaluated function cost. The pareto chart based on the finishing works in superstructure is prepared.

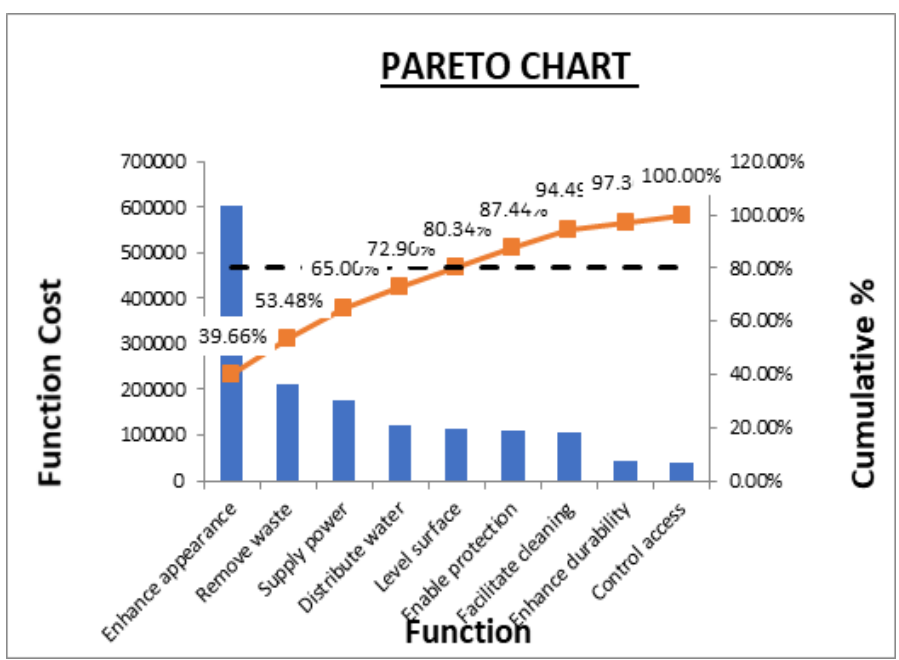

Chart -1: Pareto chart 


\section{DISCUSSION OF RESULTS}

By carrying out the Value Engineering job plan on residential building we concluded that $80 \%$ of cost for finishing works are used to enhance appearance. From Pareto chart also it is very clear that major part of the cost is used for to enhance appearance. The ideas of Value Engineering are examined again and the value of building is improved by following ideas,

- $\quad 326.4$ square meters of cement plastering is replaced by Gypsum plastering.

- Five wooden doors and windows are replaced by UPVC.

- By tiling the windowsills, cleaning is made easier.

\section{CONCLUSIONS}

By carrying out the Value Engineering job plan, the project related information were scrutinized and examined and following points were concluded;

- The information phase, have much importance to know the problem well

- The idea generation will be easier if the information are wide and plenty

- Decisions on idea selection may vary upon the relevancy of the information collected.

For getting a better out for value engineering implementation in a house building the following data are essential while information phase.

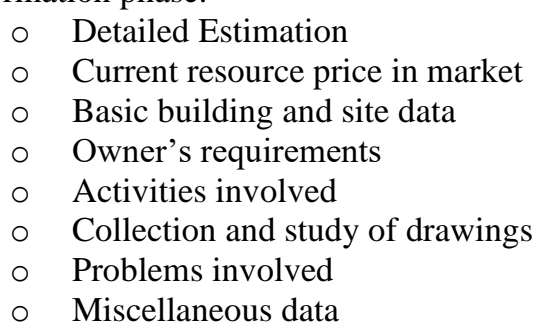

\section{ACKNOWLEDGEMENT}

Our gratitude to Almighty, our teachers, family members, friends and also acknowledge the support and help of all others who all concerned about this thesis.

\section{REFERENCES}

[1] Walaa YounesEl-Nashar, Ahmed HussienElyamany, (2018):"Value engineering for canal tail irrigation water problem", Volume 9, Issue 4.

[2] Renata Schneiderova Heralova (2016):"Possibility of Using Value Engineering in Highway Projects", Volume 164, Pages 362-367.

[3] R.Vijayan, T.ThankaGeetha, B.Nishanth, M.Tamilarasan, V.VijayaKumar (2019):"Value engineering and value analysis of rear air spring bracket", Volume 16, Part 2, Pages 1075-1082.

[4] Putri Arumsari, Ricco Tanachi (2018):" Value engineering application in a high rise building (Case study in Bali)", International Journal of Innovative Research in Advanced Engineering (IJIRAE), Volume 1.

[5] WeiTongChen, Po-YiChang, Ying-HuaHuang (2010):"Assessing the overall performance of value engineering workshops for construction projects", Volume 28, Issue 5, Pages 514-527.

[6] Senay Atabay and Niyazi Galipogullar (2013):"Application of value engineering in construction Projects", Journal of Traffic and Transportation Engineering, Volume 1.

[7] Akintola Omigbodun, (2001):" Value Engineering and Optimal Building Projects", Journal Of Architectural Engineering

[8] Xueging Zhang, Xiaoming Mao, Simaan M.AbouRizk (2009):" Developing a knowledge management system for improved value engineering practices in the construction industry", Volume 18, Issue 6, Pages 777-789. 